\title{
THE EFFECT OF Sauropus androgynus EXTRACT AND LEMURU OIL ON FAT DEPOSITION AND FATTY ACID COMPOSITION OF MEAT IN BROILER CHICKENS
}

\author{
U. Santoso, Kususiyah and Y. Fenita \\ Department of Animal Science, Faculty of Agriculture, Bengkulu University \\ Jalan Raya WR Supratman, Bengkulu - Indonesia \\ Corresponding E-mail: santosoburgo@yahoo.com
}

Received November 3, 2009; Accepted February 5, 2010

\begin{abstract}
The present study was conducted to evaluate the effect of Sauropus androgynus (katuk) leaves extract (SAE) and lemuru fish oil (LO) on fat deposition and fatty acid composition of meat in broiler chickens. One hundred and fifty six broiler chickens were distributed to 13 treatment groups with 3 cages in each treatment group as replicate. Completely randomized design was used in this study. The thirteen groups were subsequent of broiler chickens that were fed diet containing commercial feed supplement as a control (P1), $10 \mathrm{~g} / \mathrm{kg} \mathrm{SAE}$ and $1 \% \mathrm{LO}(\mathrm{P} 2) ; 10 \mathrm{~g} / \mathrm{kg}$ SAE and $1 \%$ LO plus $60 \mathrm{mg}$ vitamin E (P3), $10 \mathrm{~g} / \mathrm{kg} \mathrm{SAE}$ and $2 \% \mathrm{LO}(\mathrm{P} 4), 10 \mathrm{~g} / \mathrm{kg} \mathrm{SAE}$ and $2 \% \mathrm{LO}$ plus $60 \mathrm{mg}$ vitamin E (P5), 10 $\mathrm{g} / \mathrm{kg} \mathrm{SAE}$ and $3 \% \mathrm{LO}(\mathrm{P} 6), 10 \mathrm{~g} / \mathrm{kg} \mathrm{SAE}$ and $3 \% \mathrm{LO}$ plus $60 \mathrm{mg}$ vitamin $\mathrm{E}$ (P7), $18 \mathrm{~g} / \mathrm{kg} \mathrm{SAE}$ and $1 \%$ LO (P8), $18 \mathrm{~g} / \mathrm{kg}$ SAE and 1\% LO plus $60 \mathrm{mg}$ vitamin E (P9), $18 \mathrm{~g} / \mathrm{kg}$ SAE and $2 \%$ LO (P10), were $18 \mathrm{~g} / \mathrm{kg} \mathrm{SAE}$ and $2 \% \mathrm{LO}$ plus $60 \mathrm{mg}$ vitamin E (P11), $18 \mathrm{~g} / \mathrm{kg} \mathrm{SAE}$ and $3 \% \mathrm{LO}$ (P12), and $18 \mathrm{~g} / \mathrm{kg} \mathrm{SAE}$ and 3\% LO plus $60 \mathrm{mg}$ vitamin E (P13). The data were analyzed by analysis of variance and if it were significant, it were then determined by Duncan's Multiple Range test. The present results showed that supplementation of SAE and LO significantly affected $(\mathrm{P}<0.05)$ fat deposition in abdomen and leg, but it had no effect on neck fat deposition and Fatty Liver Score. Supplementation of SAE and LO had significantly reduced $(\mathrm{P}<0.05)$ cholesterol content and thiobarbituric acid $(\mathrm{TBA})$ in leg meat, but it significantly increased $(\mathrm{P}<0.05)$ vitamin $\mathrm{A}$ and vitamin $\mathrm{E}$ and it had no effect on fat in leg meat. Supplementation of SAE and LO proved to change fatty acid composition in leg meat. The treatment highly significant increased ecosapentaenoic acid (EPA) and docosahexaenoic acid DHA $(\mathrm{P}<0.01)$, arachidonic acid and stearic acid $(\mathrm{P}<0.05)$, but it significantly reduced linolenic acid $(\mathrm{P}<0.05)$. In conclusion, the supplementation of SAE and LO reduced fat deposition in abdomen and leg, the content of cholesterol in meat, and it enriched EPA and DHA of meat.
\end{abstract}

Keywords: cholesterol, fatty acid, fat deposition, Lemuru oil, Sauropus androgynus.

\section{INTRODUCTION}

Recently, broiler industries were faced on producing the meat with lower fat content, free antibiotic residue but high in nutrition. Unfortunately, commercial feed supplement used in the present broiler industries did not meet the demand of consumers. Furthermore, no experiment was conducted to enrich several nutrition but low in cholesterol in broiler meat.

Modified meats as mentioned above would be benefit with the following reasons: 1) nutriton in broiler meat was highly digested and absorbed as compared with other foodstuff; 2) the price of nutrition would be cheaper; 3) it would produce meat with free pathogenic microorganism and free antibiotic and drug residue; 4) broiler production would be more efficient; 5) the improvement of meat quality would be benefit for consumers, because it will decrease the occurence of stroke, coronary heart, atherosclerosis, obesity, cancer and other diseases caused by pathogenic microorganism as a result of their resistences to antibiotics (Barton and Hart, 2001; Cao et al., 1999). It has been proven that medical herbs were potential to decrease fat deposition, cholesterol, triglyceride and lipogenic enzyme activities. (Santoso et al., 2001a,b; Santoso and Sartini, 2001; Shim et al., 2004).

Sauropus androgynus is rich in mineral and containes six metabolic secundary compounds, namely monomethyl succinate, cyclopentanol, 2methyl-acetate, cis, benzoic acid, 2phenylmalonic acid, 2-pyrrolidinone and 
methylpyroglumate (Agustal et al., 1997), $\beta$ carotene (Subekti, 2003). Suprayogi (2000) found that Sauropus androgynus leaves extracted by ethanol contained cumarins, tannins, sugars, alkaloids salt, antrasenoids, steroid glycosides/ triterpenoids, flavonoids, anthocyanins and isoquinoline alkaloids. Furthermore, when they were extracted by hot water, they contained tannins, cumarins, and alkaloids salt. These compounds had an important role in improving nutritional metabolism in broiler chickens. Santoso and Sartini (2001) found that feeding 3\% Sauropus androgynus leave meal reduced fat deposition in abdomen by 35\%. Furthermre, Santoso et al. (2004) found that supplementation of $4.5 \mathrm{~g}$ Sauropus androgynus extract/ $\mathrm{kg}$ diet reduced fat deposition, total fat content, and cholesterol in broiler meat, but it enriched amino acid composition as compared with commercial feed supplement. It was therefore predicted that Sauropus androgynus may substitute commercial feed supplement. In other researches, Santoso (2001a,b,c) found that Sauropus androgynus extract supplementation at $18 \mathrm{~g} / \mathrm{kg}$ diet decreased fat deposition and Salmonella $s p$ and Escherichia coli in broiler meat. From the series of these experiments, it was concluded that supplementation of Sauropus androgynus extract might decrease fat deposition in broiler chickens.

Sauropus androgunus extract supplementation was not able to modify polyunsaturated fatty acid in broiler meat
(Santoso et al., 2004). In additon, the reduction of cholesterol may be optimum, if SAE was combined by lemuru fish oil. Lemuru fish oil was rich in polyunsaturated fatty acid (Fenita, 2002).

Therefore, the present study was conducted to produce broiler meat with low in fat but rich in polyunsaturated fatty acid by substituting commercial feed supplement with natural feed supplement, namely SAE, lemuru fish oil and vitamin E mixture.

\section{MATERIALS AND METHODS}

The present study was conducted to four steps, namely: 1) purifying lemuru fish oil, 2) Sauropus androgynus extraction, 3) broiler maintenance, 4) the analysis of laboratorium and data. Crude fish oil was purified by the method decribed by Fenita (2002) whereas Sauropus androgynus leaves were extracted by the method described by Santoso et al. (2004). Compostion of diet is presented in Table 1.

One hundred fifty six of broiler chickens aged 21 days were distributed to 13 treatment groups. Each treatment group contained 3 cages of 4 broiler chickens, respectively. The present experiment used completely randomized experimental design. The 13 treatment groups were as follows:

1) Control, Broiler chickens were fed diet containing commercial feed supplement $(\mathrm{P} 0)$;

2) Broiler chickens were fed diet containing $10 \mathrm{~g} /$

Table 1. The Compsition of Experimental Diet (\%)

\begin{tabular}{|c|c|c|c|c|c|c|c|c|c|c|c|c|c|}
\hline Feedstuff & $\mathrm{P} 0$ & $\mathrm{P} 1$ & $\mathrm{P} 2$ & P3 & $\mathrm{P} 4$ & P5 & P6 & P7 & P 8 & P9 & P 10 & P 11 & P 12 \\
\hline Corn & 55.1 & 55.1 & 55.1 & 55.1 & 55.1 & 55.1 & 55.1 & 54.3 & 54.3 & 54.3 & 54.3 & 54.3 & 54.3 \\
\hline Palm oil & 6.53 & 5.53 & 5.53 & 4.53 & 4.53 & 3.53 & 3.53 & 5.53 & 5.53 & 4.53 & 4.53 & 3.53 & 3.53 \\
\hline Soybean meal & 29.6 & 29.6 & 29.6 & 29.6 & 29.6 & 29.6 & 29.6 & 29.6 & 29.6 & 29.6 & 29.6 & 29.6 & 29.6 \\
\hline Fish meal & 4.7 & 4.7 & 4.7 & 4.7 & 4.7 & 4.7 & 4.7 & 4.7 & 4.7 & 4.7 & 4.7 & 4.7 & 4.7 \\
\hline $\begin{array}{l}\text { Calsium } \\
\text { carbonate }\end{array}$ & 1.32 & 1.32 & 1.32 & 1.32 & 1.32 & 1.32 & 1.32 & 1.32 & 1.32 & 1.32 & 1.32 & 1.32 & 1.32 \\
\hline Mineral mixuture & 1.35 & 1.35 & 1.35 & 1.35 & 1.35 & 1.35 & 1.35 & 1.35 & 1.35 & 1.35 & 1.35 & 1.35 & 1.35 \\
\hline Sodium & 0.4 & 0.4 & 0.394 & 0.4 & 0.394 & 0.4 & 0.394 & 0.4 & 0.394 & 0.4 & 0.394 & 0.4 & 0.394 \\
\hline $\begin{array}{l}\text { Commercial } \\
\text { feed supplement }\end{array}$ & 1 & 0 & 0 & 0 & 0 & 0 & 0 & 0 & 0 & 0 & 0 & 0 & 0 \\
\hline $\begin{array}{l}\text { Sauropus } \\
\text { extract }\end{array}$ & 0 & 1 & 1 & 1 & 1 & 1 & 1 & 1.8 & 1.8 & 1.8 & 1.8 & 1.8 & 1.8 \\
\hline Lemuru fish oil & 0 & 1 & 1 & 2 & 2 & 3 & 3 & 1 & 1 & 2 & 2 & 3 & 3 \\
\hline Vitamin E & 0 & 0 & 0.006 & 0 & 0.006 & 0 & 0.006 & 0 & 0.006 & 0 & 0.006 & 0 & 0.006 \\
\hline
\end{tabular}


Table 2. Effect of Sauropus androgynus Extract and Lemuru Fish Oil plus Vitamin E on Fat Deposition

\begin{tabular}{lcccccccccccccc}
\hline $\begin{array}{l}\text { Variable } \\
\text { (\% BW) }\end{array}$ & P0 & P1 & P2 & P3 & P4 & P5 & P6 & P7 & P8 & P9 & P10 & P11 & P12 \\
\hline $\begin{array}{l}\text { Abdominal } \\
\text { fat }\end{array}$ & $3,00^{\mathrm{c}}$ & $1,76^{\mathrm{a}}$ & $1,81^{\mathrm{a}}$ & $2,13^{\mathrm{a}}$ & $2,49^{\mathrm{ab}}$ & $1,55^{\mathrm{a}}$ & $1,75^{\mathrm{a}}$ & $1,85^{\mathrm{a}}$ & $2,28^{\mathrm{a}}$ & $1,91^{\mathrm{a}}$ & $2,2^{\mathrm{a}}$ & $2,00^{\mathrm{a}}$ & $2,00^{\mathrm{a}} *$ \\
Neck fat & 0,04 & 0,03 & 0,05 & 0,06 & 0,05 & 0,06 & 0,06 & 0,04 & 0,05 & 0,08 & 0,04 & 0,04 & 0,05 \\
\end{tabular}

FLS $=$ Fatty liver score; P0 = Control (broiler was fed diet containing commercial feed supplement; P1 = Broiler chickens were fed diet containing $10 \mathrm{~g} / \mathrm{kg}$ Sauropus androgynus extract (SAE) plus $1 \%$ lemuru fish oil (LO); P2 = Broiler chickens were fed diet containing $10 \mathrm{~g} / \mathrm{kg} \mathrm{SAE}$ and $1 \% \mathrm{LO}$ plus $60 \mathrm{mg}$ vitamin E; P3 = Broiler chickens were fed diet containing $10 \mathrm{~g} / \mathrm{kg} \mathrm{SAE}$ and $2 \% \mathrm{LO} ; \mathrm{P} 4=$ Broiler chickens were fed diet containing $10 \mathrm{~g} / \mathrm{kg} \mathrm{SAE}$ and $2 \%$ LO plus $60 \mathrm{mg}$ vitamin E; P5 = Broiler chickens were fed diet containing $10 \mathrm{~g} / \mathrm{kg} \mathrm{SAE}$ and 3\% LO; P6 = Broiler chickens were fed diet containing $10 \mathrm{~g} / \mathrm{kg}$ SAE and 3\% LO plus $60 \mathrm{mg}$ vitamin E; P7 = Broiler chickens were fed diet containing $18 \mathrm{~g} / \mathrm{kg} \mathrm{SAE}$ and $1 \% \mathrm{LO} ; \mathrm{P} 8=$ Broiler chickens were fed diet containing $18 \mathrm{~g} / \mathrm{kg}$ SAE and $1 \% \mathrm{LO}$ plus $60 \mathrm{mg}$ vitamin E; P9 = Broiler chickens were fed diet containing $18 \mathrm{~g} / \mathrm{kg} \mathrm{SAE}$ and $2 \%$ LO; P10 = Broiler chickens were fed diet containing $18 \mathrm{~g} / \mathrm{kg} \mathrm{SAE}$ and $2 \% \mathrm{LO}$ plus vitamin E; P11 = Broiler chickens were fed diet containing $18 \mathrm{~g} / \mathrm{kg} \mathrm{SAE}$ and 3\% LO; P12 = Broiler chickens were fed diet containing $18 \mathrm{~g} / \mathrm{kg}$ SAE and 3\% LO plus $60 \mathrm{mg}$ vitamin E (P12).

Table 3. Effect of Sauropus androgynus Extract and Lemuru Fish Oil plus Vitamin E on Cholesterol Content, Total Fat, Vitamin A, Vitamin E and TBA in Leg Meat

\begin{tabular}{lccccccccccccc}
\hline \multicolumn{1}{c}{ Variabel } & P0 & P1 & P2 & P3 & P4 & P5 & P6 & P7 & P8 & P9 & P10 & P11 & P12 \\
\hline Total fat (\%) & 4,42 & 4,17 & 4,08 & 4,23 & 4,12 & 3,94 & 3,86 & 3,34 & 3,65 & 3,80 & 3,17 & 3,02 & $3,15^{\text {ns }}$ \\
Cholesterol (mg/100 mg) & $1,98^{\mathrm{d}}$ & $1,93^{\mathrm{d}}$ & $1,84^{\mathrm{d}}$ & $1,58^{\mathrm{c}}$ & $1,63^{\mathrm{c}}$ & $1,32^{\mathrm{b}}$ & $1,42^{\mathrm{bc}}$ & $1,11^{\mathrm{a}}$ & $1,63^{\mathrm{c}}$ & $1,32^{\mathrm{b}}$ & $1,37^{\mathrm{b}}$ & $1,1^{\mathrm{a}}$ & $1,16^{\mathrm{a}^{*}}$ \\
TBA (mg/kg) & $0,423^{\mathrm{f}}$ & $0,368^{\mathrm{c}}$ & $0,339^{\mathrm{c}}$ & $0,207^{\mathrm{d}}$ & $0,179^{\mathrm{c}}$ & $0,142^{\mathrm{b}}$ & $0,165^{\mathrm{c}}$ & $0,423^{\mathrm{f}}$ & $0,368^{\mathrm{a}}$ & $0,130^{\mathrm{b}}$ & $0,149^{\mathrm{b}}$ & $0,133^{\mathrm{b}}$ & $0,071^{\mathrm{a}^{*}}$ \\
Vitamin A ( $\mu \mathrm{g} / 100 \mathrm{~g})$ & $255,2^{\mathrm{a}}$ & $238,8^{\mathrm{a}}$ & $282,5^{\mathrm{ab}}$ & $221,2^{\mathrm{a}}$ & $261,9^{\mathrm{a}}$ & $285,8^{\mathrm{ab}}$ & $274,2^{\mathrm{b}}$ & $287,6^{\mathrm{b}}$ & $290,9^{\mathrm{b}}$ & $290,6^{\mathrm{b}}$ & $329,4^{\mathrm{b}}$ & $299,0^{\mathrm{b}}$ & $313,7^{\mathrm{b}^{*}}$ \\
Vitamin E $(\mathrm{mg} / 100 \mathrm{~g})$ & $0,264^{\mathrm{a}}$ & $0,347^{\mathrm{b}}$ & $0,42^{\mathrm{c}}$ & $0,41^{\mathrm{c}}$ & $0,382^{\mathrm{b}}$ & $0,432^{\mathrm{c}}$ & $0,31^{\mathrm{ab}}$ & $0,369^{\mathrm{c}}$ & $0,346^{\mathrm{b}}$ & $0,373^{\mathrm{c}}$ & $0,309^{\mathrm{ab}}$ & $0,374^{\mathrm{b}}$ & $0,305^{\mathrm{ab}^{*}}$ \\
\hline
\end{tabular}

$\mathrm{kg}$ Sauropus androgynus extract (SAE) plus $1 \%$ lemuru fish oil (LO) (P1);

3) Broiler chickens were fed diet containing $10 \mathrm{~g} /$ $\mathrm{kg}$ SAE and $1 \%$ LO plus $60 \mathrm{mg}$ vitamin $\mathrm{E}$ (P2);

4) Broiler chickens were fed diet containing $10 \mathrm{~g} /$ $\mathrm{kg} \mathrm{SAE}$ and 2\% LO (P3);

5) Broiler chickens were fed diet containing $10 \mathrm{~g} /$ $\mathrm{kg}$ SAE and $2 \%$ LO plus $60 \mathrm{mg}$ vitamin $\mathrm{E}$ (P4);

6) Broiler chickens were fed diet containing $10 \mathrm{~g} /$ $\mathrm{kg} \mathrm{SAE}$ and 3\% LO (P5);

7) Broiler chickens were fed diet containing $10 \mathrm{~g} /$ $\mathrm{kg}$ SAE and 3\% LO plus $60 \mathrm{mg}$ vitamin $\mathrm{E}$ (P6);

8) Broiler chickens were fed diet containing 18 $\mathrm{g} / \mathrm{kg} \mathrm{SAE}$ and $1 \% \mathrm{LO}(\mathrm{P} 7)$;
9) Broiler chickens were fed diet containing 18 $\mathrm{g} / \mathrm{kg} \mathrm{SAE}$ and $1 \%$ LO plus $60 \mathrm{mg}$ vitamin $\mathrm{E}$ (P8);

10) Broiler chickens were fed diet containing 18 $\mathrm{g} / \mathrm{kg} \mathrm{SAE}$ and $2 \%$ LO (P9);

11) Broiler chickens were fed diet containing 18 $\mathrm{g} / \mathrm{kg} \mathrm{SAE}$ and $2 \%$ LO plus vitamin E (P10);

12) Broiler chickens were fed diet containing 18 $\mathrm{g} / \mathrm{kg} \mathrm{SAE}$ and $3 \%$ LO (P11);

13) Broiler chickens were fed diet containing 18 $\mathrm{g} / \mathrm{kg} \mathrm{SAE}$ and $3 \% \mathrm{LO}$ plus $60 \mathrm{mg}$ vitamin $\mathrm{E}$ (P12).

Broiler chickens were fed experimental diet at finisher period ( $21-42$ days of age). Diet and drinking water were fed ad libitum.

At the end of the experiment, 4 broiler chickens ( 2 male and 2 female) of each treatment 
Table 4. Effect of Sauropus androgynus Extract and Lemuru Fish Oil plus Vitamin E on the Composition of Fatty Acid in Leg Meat (\%)

\begin{tabular}{lccccccccccc}
\hline Treat & Miristic & Palmitic & Palmitoleic & Stearic & Oleic & Linoneic & Linolenic & Arakhidonic & EPA & DHA \\
\hline P0 & 0.602 & 17.710 & 7.682 & 2.863 & 39.964 & 13.714 & 1.211 & 0.254 & $0^{\mathrm{a}}$ & $0^{\mathrm{a}}$ \\
P1 & 0.631 & 16.734 & 9.560 & 6.034 & 40.826 & 17.510 & 0.961 & 0.689 & $0.015^{\mathrm{b}}$ & $0.017^{\mathrm{b}}$ \\
P2 & 1.074 & 21.578 & 7.496 & 4.797 & 45.108 & 15.903 & 0.618 & 0.261 & $0.016^{\mathrm{b}}$ & $0.014^{\mathrm{b}}$ \\
P3 & 0.620 & 22.721 & 6.764 & 5.783 & 43.020 & 16.408 & 0.534 & 0.346 & $0.009^{\mathrm{b}}$ & $0.012^{\mathrm{b}}$ \\
P4 & 0.803 & 23.990 & 7.730 & 5.547 & 42.749 & 13.792 & 0.447 & 0.583 & $0.058^{\mathrm{c}}$ & $0.051^{\mathrm{b}}$ \\
P5 & 0.715 & 22.861 & 7.497 & 5.128 & 43.427 & 16.162 & 0.565 & 0.626 & $0.012^{\mathrm{b}}$ & $0.031^{\mathrm{b}}$ \\
P6 & 0.746 & 23.813 & 10.497 & 5.182 & 44.766 & 11.859 & 0.490 & 0.419 & $0.541^{\mathrm{f}}$ & $0.207^{\mathrm{c}}$ \\
P7 & 0.598 & 23.769 & 5.030 & 5.921 & 43.911 & 16.395 & 0.346 & 0.418 & $0.359^{\mathrm{e}}$ & $0.469^{\mathrm{a}}$ \\
P8 & 0.700 & 23.013 & 8.917 & 5.074 & 40.914 & 14.644 & 0.590 & 0.203 & $0.76^{\mathrm{g}}$ & $0.938^{\mathrm{a}}$ \\
P9 & 0.636 & 22.787 & 8.536 & 4.671 & 45.236 & 14.669 & 0.863 & 0.563 & $0.261^{\mathrm{d}}$ & $0.312^{\mathrm{d}}$ \\
P10 & 0.860 & 21.010 & 7.093 & 4.252 & 40.968 & 15.061 & 0.918 & 0.967 & $1.32^{\mathrm{h}}$ & $1.097^{\mathrm{a}}$ \\
P11 & 1.210 & 22.120 & 7.999 & 4.990 & 40.803 & 13.143 & 0.645 & 0.526 & $0.018^{\mathrm{b}}$ & $0.355^{\mathrm{a}}$ \\
P12 & 0.706 & 21.483 & 6.017 & 6.031 & 40.970 & 18.549 & 0.570 & 0.411 & $0.818^{\mathrm{g}}$ & $1.165^{\mathrm{a}}$ \\
& $\mathrm{P}<0.05$ & $\mathrm{NS}$ & $\mathrm{NS}$ & $\mathrm{P}<0.05$ & $\mathrm{NS}$ & $\mathrm{NS}$ & $\mathrm{P}<0.05$ & $\mathrm{P}<0.05$ & $\mathrm{P}^{2}<0.01$ & $\mathrm{P}<0.01$ \\
\hline
\end{tabular}

group were slaughtered, and abdominal and neck fats were collected and weighed. Fatty Liver Score was scored by comparing the color of liver broiler chickens with the standard. Leg meats were removed and stored in sealed plastic bag and stored in freezer before analizing for cholesterol, total fat, fatty acid composition, vitamin A, vitamin $\mathrm{E}$ and thiobarbituric acid (TBA) content.

To determine fatty acid composition of meat, total fat of meat was extracted by the method of Folch et al. (1957), and it was then methylized by $20 \%$ boron trifluoride methanol complex within methanol solution (Morrison and Smith, 1964). Fatty acid composition was determined by gas chromatography. Oxidation was determined by measuring malonaldehyde (MDA) as secondary oxidation product as described by Botsoglou et al. (1994). Total fat was determined by the method of AOAC (1980), and cholesterol was determined by the method of Liebermann-Burchard (Fenita, 2002).

All data were analyzed by analysis of variance and if they were significantly different they were determined by Duncan's Multiple Range test.

\section{RESULTS AND DISCUSSION}

Effect of SAE and LO on fat deposition in broiler chickens was shown in Table 2 .
Experimental results showed that supplementation of SAE and LO significantly reduced fat deposition in abdomen $(\mathrm{P}<0.05)$ and sartorial $(\mathrm{P}<0.05)$, but it had no effect on fat deposition in neck $(\mathrm{P}>0.05)$ and Fatty Liver Score $(\mathrm{P}>0.05)$. The reduction of fat deposition might partly be caused by methylpyroglutamate. Methylpyroglutamate may be converted to glutamic acid in the gut (Santoso et al., 2005). It was known that glutamic acid was effective to reduce fat deposition in poultry. Glutamic acid is intermediate compound in certain amino acid and stimulates protein synthesis. The increment of protein synthesis would reduce the substrate for fatty acid synthesis. The reduction of fatty acid synthesis might partly reduce fat deposition. In additon, SAE was rich in saponin, flavonoid, and tannin. These compounds were known to have antilipidemic properties. In additon, polyunsaturated fatty acid of lemuru fish oil might also have important role in fat deposition reduction. Table 3 shows the effect of SAE and $\mathrm{LO}$ on cholesterol, total fat, vitamin A, vitamin $\mathrm{E}$ and TBA in leg meat. Experimental results showed that supplementation of SAE and LO reduced cholesterol content $(\mathrm{P}<0.05)$ and TBA $(\mathrm{P}<0.05)$ in leg meat, but it increased vitamin $\mathrm{A}$ $(\mathrm{P}<0.05)$ and vitamin $\mathrm{E}(\mathrm{P}<0.05)$. However, it was not significantly reduced total fat in leg meat $(\mathrm{P}>0.05)$. The tendency of reduction of total fat 
and/or cholesterol in leg meat might be partly caused by methylpyroglutamate and polyunsaturated fatty acid. These compounds were known to have antipilidemic properties (Fenita, 2002, Santoso et al., 2004). In addition, SAE also contained flavonoid, tannin and other alkaloids in which these compounds also had antilipidemic properties. Suprayogi (2000) found that Sauropus androgynus leaves extracted by ethanol contained cumarins, tannins, sugars, alkaloids salt, antrasenoids, steroid glycosides/triterpenoids, flavonoids, anthocyanins and isoquinoline alkaloids. Furthermore, when they were extracted by hot water, they contained tannins, cumarins, and alkaloids salt. It needed further experiment to elucidate the mechanism of cholesterol reduction by SAE and LO. Shim et al. (2004) found that cholesterol reduction by medical herbs (e.g. Codonopsis lanceolata) was in part be caused by the increment of cholesterol excretion via bile acid. Fenita (2002) found that polyunsaturated fatty acid reduced cholesterol content in broiler meat.

The reduction of cholesterol in $\mathrm{P} 5, \mathrm{P} 7, \mathrm{P} 9$, $\mathrm{P} 10, \mathrm{P} 11$ and $\mathrm{P} 12$ had a commercial meaning in broiler industries, because the Food and Drug Administration in the United States (1997) stated that a product has lower cholesterol than normal, if the reduction of cholesterol should be at least $25 \%$ than normal.

Supplementation of $18 \mathrm{~g} \mathrm{SAE}$ and LO (1\%, $2 \%$ or $3 \%$ ) was effective to increase vitamin $\mathrm{A}$ in leg meat. It is a logic result, because SAE is rich $\beta$-carotene (Subekti, 2003), whereas LO is rich in vitamin $A$. It is interesting that the supplementation of $10 \mathrm{~g} \mathrm{SAE}$ and LO $(1 \%, 2 \%$ or $3 \%$ ) had no effect on vitamin A. This result showed that level of SAE was more dominant than LO to increase vitamin A in leg meat. However, LO was more dominant in contributing vitamin $\mathrm{E}$ increment. It is logic, because $\mathrm{SAE}$ contained no vitamin $\mathrm{E}$, whereas $\mathrm{LO}$ is rich in vitamin E.

Table 4 presents the effect of SAE and LO on fatty acid composition in leg meat. Experimental results showed that supplementation of SAE and LO changed fatty acid composition. Supplementation of LO highly significant increased $(\mathrm{P}<0.01)$ ecosapentaenoic acid (EPA), and docosahexaenoic acid (DHA), significantly increased $(\mathrm{P}<0.05)$ stearic acid and arachidonic acid. However, the incretion in EPA and DHA were accompanied by lower linolenic acid $(\mathrm{P}<0.05)$. Supplementation of SAE did not increase linoleic acid and palmitic acid, although SAE was rich in linoleic acid and palmitic acid (Santoso et al., 2004).

Addition of n-3 polyunsaturated fatty acid (PUFA) to the diet might cause the change in reaction system in the body such as change in saturated fatty acid composition would change the synthesis of lipoprotein, saturated fatty acid metabolism, growth factor, and other reaction in the body (Drevon, 1989). Consumption of n-3 PUFA from fish might reduce the risk of coronary heart diseases (Eritsland et al., 1994; Leaf et al., 1995). Furthermore, the consumption of fish oil was effective to treat hypertriglyceride as a result of very low density lipoprotein (VLDL) synthesis (Liepa and Godman, 1991). Fish oil has antiaggregation properties, and the addition of fish oil would effectively decrease plasma triglyceride (Eritsland et al., 1994; Layne et al., 1996; Seidelin et al., 1992).

The reduction of TBA in treatment groups showed that supplementation of SAE with/without vitamin E would prevent the increasing of fatty acid oxidation as a result of LO supplementation.

\section{CONCLUSION}

In conclusion, supplementation of Sauropus androgynus extract and lemuru fish oil reduced fat deposition and meat cholesterol, but it increased the content of vitamin A and vitamin E in broiler meat. Supplementation of lemuru fish oil increased EPA, DHA, stearic acid and arachidonic acid but decreased linolenic acid in meat. In addition, fatty acid oxidation increment as a result of lemuru fish oil supplementation could be prevented by Sauropus androgynus extract in combination with/without vitamin E.

\section{ACKNOWLEDGMENT}

The present experiment was supported by Directorate General High Education, Department of National Education under contract number: 1780/H30.10.06.01/HK/2009 dated February 2, 2009.

\section{REFERENCES}

Agustal, A., M. Harapini and Chairul. 1997. Analisis kandungan kimia ekstrak daun katuk (Sauropus androgynus (L) Merr dengan GCMS. Warta Tumbuhan Obat 
Indonesia 3 (3): 31-33.

AOAC. 1980. Official Methods of Analysis. 11 ed. Association of Official Analytical Chemist, Washington, D.C.

Barton, M. D. and W. S. Hart. 2001. Public health risks: Antibiotic resistance- A review. AsianAust. J. Anim. Sci. 14: 414-422.

Botsoglou, N. A., D. J. Fletouris, G. E. Papageorgion, V. N. Vassilopoulos, A. J. Mantis and A. G. Trakatellis. 1994. Rapid, sensitive and specific thiobarbituric acid method for measuring lipid peroxidation in animal tissue, food and feedstuff samples. J. Agric. Food Chem. 42: 1931-1937.

Cao, J., K. Li, X. Lu and Y. Zhao. 2004. Effects of florfenical and chromium (III) on humoral immune response in chicks. Asian-Aust. J. Anim. Sci. 17: 366-370.

Chen, J. Y., J. D. Latshaw, H. O. Lee and D. B. Min. 1998. $\alpha$-tocopherol content and oxidative stability of egg yolk as related to dietary $\alpha$-tocopherol. J. Food Sci. 63: 919922.

Drevon, C. A. 1989. W-3 fatty acids in health and disease. In: Fish, Fats and Your Health. Procedings of the International Conference on Fish Lipid and Their Influence on Human Health. Norwey.

Eritsland, J., H. Arnesen, I. Seljeflot and A. T. Hostmark. 1994. Long-term metabolic effect of n-3 polyunsaturated fatty acids in patient with coronary diets artery disease. Am. J. Clin. Nutr. 61: 831-836.

Fenita, Y. 2002. Suplementasi Lisin dan Metionin serta Minyak Lemuru ke dalam Ransum Berbasis Hidrolisat Bulu Ayam terhadap Perlemakan dan Pertumbuhan Ayam Ras Pedaging. Dissertation, IPB, Bogor.

Folch, J., M. Lees and G. H. Sloane Stanley. 1957. A simple method for isolation and porification of total lipids from animal tissues. J. Biol. Chem. 226: 497-509.

Food and Drug Administration of the United States. 1997. A Food Labeling Guide Appendix A: Definitions of Nutrient Content Claims. Center for Food and Safety and Applied Nutrition, Washington, DC.

Jandacek, R. J., E. J. Hollenbach, B. N. Holcombe, C. M. Kuehlhau, J. C. Peters and J. D. Taulbee. 1991. Reduced storage of dietary eicosapentaenoic and docosahexaenoic acid in the weanling rat. J. Nutr. Biochem 2: 142-149.
Layne, K. S., Y. K. Gob, J. A. Jumpsen, E. A. Ryan, P. Chow and M. T. Clandinin. 1996. Normal subjects consuming physiological levels of 18:3 (n-3) and 20:5 (n-3) from flaxseed or fish oils have characteristic differences in plasma lipid and lipoprotein in fatty acid levels. J. Nutr. 126: 2130-2140.

Leaf, D. A., W. E. Connor, L. Barstad and G. Sexton. 1995. Incorporation of dietary n-3 fatty acids into the fatty acids of human adipose tissue and plasma lipid classes. Am. J. Clin. Nutr. 62: 68-73.

Liepa, G. U. and M. A. Gorman. 1991. Nutritional and health aspects of dietary lipids in introduction to fats and oil technology. Edited by P. J. Wan. American Oil Chemists Society, Cahmpaign, Illinois.

Morrison, W. R. and M. L. Smith. 1964. Preparation of fatty acid methyl esters and dimethylacetates from lipid with boron trifluoride methanol. J. Lipid Res. 5: 600608.

Santoso, U. 2001a. Effect of Sauropus androgynus Extract on the Carcass Quality of Broiler Chicks. Buletin Ilmu Peternakan dan Perikanan 7: 22-28.

Santoso, U. 2001b. Effect of Sauropus androgynus Extract on the Performance of Broiler. Buletin Ilmu Peternakan dan Perikanan 7: 15-21.

Santoso, U. 2001c. Effect of Sauropus androgynus Extract on Organ Weight, Toxicity and Number of Salmonella $s p$ and Escherichia coli of Broilers Meat. Buletin Ilmu Peternakan dan Perikanan, 7 (2): 162169.

Santoso, U., S. Ohtani and K. Tanaka. 2001a. Tuchung leaf meal supplementation reduced an increase in lipid accumulation of chickens stimulated by dietary cholesterol. AsianAust. J. Anim. Sci. 13: 1758-1763.

Santoso, U., Suharyanto and E. Handayani. 2001b. Effects of Sauropus androgynus (katuk) leaf extract on growth, fat accumulation and fecal microorganisms in broiler chickens. J. Ilmu Ternak dan Vet., 6: 220-226.

Santoso, U., Y. Fenita and W. Piliang. 2004. Penggunaan Ekstrak Daun Katuk sebagai Feed Additive untuk Memproduksi Meat Designer. Research Report, Bengkulu University, Bengkulu.

Santoso, U. and Sartini. 2001. Reduction of fat accumulation in broiler chickens by 
Sauropus androgynus (Katuk) leaf meal supplementation. Asian-Aust. J. Anim. Sci. 14: 346-350.

Santoso, U., J. Setianto and T. Suteky. 2005. Effects of Sauropus androgynus (katuk) extract on egg production and lipid metabolism in layers. Asian-Australasian J. Anim. Sci. 18: 364-369.

Seidelin, K. N., B. Myrup and B. Fisher-Hamsen. 1992. N-3 fatty acid in adipose tissue and coronary artery diseases are inversely related. Am. J. Clin. Nutr. 55: 117-119.

Shim, K. S., G. H. Park, C. J. Choi and C. S. Na. 2004. Decreased triglyceride and cholesterol levels in serum, liver and breast muscle in broiler by supplementation of dietary Codonopsis lonceolara root. Asian-Aust. J. Anim. Sci. 17: 511-513.

Subekti, S. 2003. Kualitas Telur dan Karmas Ayam Local yang Diberi Tepung Daun Katuk dalam Ransum. Thesis, IPB. Bogor.

Suprayogi, A. 2000. Studies on the Biological Effets of Sauropus androgynus (L.) Merr: Effects on Milk Production and the Possibilities of Induced Pulmonary Disorder in Lactating Sheep. Cuviller Verlag Gottingen. 